\title{
\begin{tabular}{r|r}
$\begin{array}{r}\text { indigenous } \\
\text { existentialism and }\end{array}$ & the body \\
BRENDAN HOKOWHITU
\end{tabular}
}

This article initiates a discussion surrounding 'indigenous existentialism'. To prefigure the conversation it is important to realise that, as a canonical field, 'Indigenous studies' does not exist. Any pan-Indigenous studies analyses, which may exist, focus around either the purity of a mythical pre-colonial past and/or 'decolonisation'. Meaning, Indigenous studies is largely divorced from the immediacy of the Indigenous condition. In turn, this indicates the extent that cultural studies could influence Indigenous studies because of the import cultural studies places on reading the texts of the 'everyday'. The article seeks to develop a focus on the immediacy of the Indigenous condition through theorising the 'Indigenous body'. Here, a brief genealogy of the Indigenous body is provided to stress that before proceeding the colonial ghosts haunting the Indigenous body must necessarily be exhumed. That is, the epistemological mind/body dualism of the Enlightenment and, thus, colonisation, must be deconstructed prior to conceptualising the body as a site of research where Indigenous existentialism can be probed. More significant to the project of Indigenous existentialism is the actual theorisation of the immediacy of the Indigenous body. The importance of Foucault's 'biopower' to this analysis is relayed, yet the full implications of such a conception of power are dismissed in order to conceive of the Indigenous body as recognisable beyond the invisibility of such a power complex; rejecting the idea of the Indigenous body as passive material inscripted upon, in favour of its materialisation as an existential 'active biological entity'. Such theorisation makes possible Indigenous existentialism in arguing that the morphing body through time is both changed by, and can change, its facticity, while importantly moving beyond the mind/body dualism at the heart of the savage constructions of Indigenous peoples. 
Regardless of the Indigenous condition, choice, freedom and responsibility, especially, are proposed as necessary constituents to an Indigenous existentialism.

$-\mathrm{I}$

\section{Reflections on Indigenous Studies}

\section{Situating Indigenous studies}

A handful of Indigenous scholars have attempted to conceive of the tenets underpinning a universal Indigenous studies, while others have conducted comparative work across colonial contexts. Still others have theorised at a universal level and/or examined the impact of global events upon Indigenous people. Indeed, the inevitable impulsion to produce internationally recognised scholarship within Western academia has compelled many Indigenous writers to theorise their local context within theoretical frameworks that enable dialogue across colonial contexts. Yet, such dialogues are often epistemologically limited because of the ontological importance of local contexts, languages and cultures. Indeed, Indigenous scholars are often left in the unenviable position of finding common ground (that is, 'Indigenous studies') within the ontological violence of colonialism. Nevertheless, pan-Indigenous scholars continue to meet and share ideas on a regular basis, fuelling an organic universal conceptualisation of Indigenous studies.

Having said this, for fruitful discussions surrounding 'Indigenous studies' to develop it is important to first recognise that as a canonical field 'Indigenous studies' does not exist. Its genesis has been ad hoc, yet organic, in the sense that the amorphous concept of 'Indigenous studies' has arisen out of pre-established local departments, such as Mäori studies in New Zealand, Aboriginal studies in Australia and Native studies departments in the US and Canada. Indeed, such departments remain the strongholds in the various local contexts, while Indigenous studies per se is a very recent auxiliary to localised core curricula.

Typically, local departments have historically developed as subdivisions of larger faculties such as anthropology with their own established canons. Indigenous studies, thus, lacks any semblance of a coherent genealogy from which it can build, in large part because it has borrowed multilaterally from various disciplines, while trying to account for a diverse range of Indigenous contexts. This is not to say, however, that Mäori studies or Australian Aboriginal or Native American studies and so on necessarily lack a coherent genealogy within their own distinct context. Yet, the broader genealogical incongruence and orphan-like history suggest the genesis of a universal-like Indigenous studies is at best embryonic. From this point forth, therefore, when referring to 'Indigenous studies', it is not in reference to any semblance of an Indigenous studies field of study, for there is yet to be any cogency in this regard. Rather, the nomenclature refers to localised Indigenous studies as an incongruent collective, still to be signified by such a universalising taxonomy. 
Much of the above may seem obvious, yet it is important to point to the problematics of choosing to represent localised Indigenous cultures under the unifying idea of 'indigeneity'. It is extremely important that the universalising and reductive concept of indigeneity does not pretend to have the capabilities to underpin local Indigenous studies departments, lest we follow the universalising footsteps of European modernism. Such inattention to the local Indigenous condition inherently devalues the very concept of indigeneity because of its tithing to place. Thus, Mäori studies, for instance, must remain as Mäori studies and so forth. Regardless, Indigenous peoples will continue to theorise their existence through the sharing and comparison of localised knowledges, for it is the complexity of the 'glocal' Indigenous positioning that demands and will determine the development of a more coherent multilayered Indigenous studies discipline.

\section{Epistemological reflections: 'tradition', 'decolonisation' and 'ressentiment'}

There has been, in Mäori studies at least, a tendency to conceive of language and culture as 'traditional' and to focus on the 'preservation' of culture. One of the tactical moves of colonial discourse 'is to present the colonial subject as unchanging and immutable"1 and many Indigenous scholars have themselves canonised tradition in their re-search. Such a focus is debilitating when predicated upon the search for a nonexistent authentic precolonial past. Ironically, it was the destabilisation and rupture of culture and identity caused by colonisation, leading to cultural insecurity, that has rendered the search for secure and 'authentic' precolonial Indigenous cultures. Such a focus on past traditions and authenticity disables cultural critique and assumes any authenticating cultural project is even possible. Below, Mäori academic Clea Te Kawehau Hoskins challenges the status quo:

Because this knowledge is sourced in a world and time we know little about, we feel almost completely unable to be critical of it. Rather we tend to accept and take up uncritically such discourses, placing our trust in those keepers and interpreters of what is promoted as 'authentic' genuine Mäori knowledge, practice and thought ... to add to this you may be accused of not being a 'real Mäori', not 'tuturu' [true], or being a 'colonised-in-the-mind Mäori'. ${ }^{2}$

Fundamentally, the search for pure traditions and precolonial authentic identities relocates an Indigenous sense-of-being in the past. In so doing, it fixes what should constantly be in flux (that is, culture) and, in turn, debilitates Indigenous existentialism. The idealism Indigenous people locate in the pure-past limits how we conceive of ourselves through the immediacy of experience.

Indigenous studies needs attention to the past, future and, most significant to this essay, the immediacy of the here and now; 'the everyday'. The 'everyday' in Indigenous scholarship is either positioned in terms of Indigenous political struggles, especially in regard to 
jurisprudence, or in terms of 'victimhood' conceived of as the genealogical descendant of the trauma of colonisation. Such scholarship is necessarily reactionary as opposed to existential. For instance, according to Gerald Alfred, 'It has been said that being born Indian is being born into politics ... because being born a Mohawk of Kahnawake, I do not remember a time free from the impact of political conflict'. ${ }^{3}$ Perhaps the 'facticity' of the matter, that is, the situation colonised Indigenous peoples face, imposes the colonial condition upon us, but certainly I desire for myself and my children a future where entry into political conflict is a choice, not a preordainment.

Likewise, the production of decolonial theory in its very nomenclature demands an understanding of the philosophies and history of the colonists in order to understand the genealogy of power in the colonial context. Accordingly, decolonial theory has developed as re-scholarship where alternative knowledges are re-inserted into text so Indigenous people can deconstruct occidental history to produce alternative histories. For instance, Linda Smith argues:

Transforming our colonized views of our own history (as written by the West) ... requires us to revisit, site by site, our history under Western eyes. This in turn requires a theory or approach, which helps us to engage with, understand and then act upon history'. ${ }^{4}$

A worthy project, yet we must at least question the semantics of the project of 'decolonisation' for what does that actually mean, and if we could ever define it, is it actually possible? I suggest a more valuable project is one of Indigenous existentialism, and inherent to this project would be discussions surrounding the immediacy of Indigenous culture and, thus, the relevance of cultural studies.

Unfortunately, I cannot begin to define what cultural studies is because, like Indigenous studies, there seems to me to be many concurrent and competing projects, none of which I am particularly familiar with. As outlined above, however, I am most interested in the aspect of cultural studies that concerns itself with the meaning and practices of everyday life. Although I do not have the space to go into it in any depth here, there is some resonance in a comparative analysis of Indigenous studies and cultural studies in the sense of a shift from a Marxist tradition to a reconceptualisation of power as less hierarchical. From the 1970s, the politically minded Indigenous scholars characteristically aligned themselves with hegemony theory, to the extent that if there existed a cogent polemical Indigenous studies common ground, it crystallised around this theory, or what has been caricatured as 'a 1970s Indian', in reference to the idolatry and, perhaps, now unhelpful nature of a relationship between Indigenous studies and hegemony theory.

Some Indigenous theorists are moving beyond the construction of power through hegemony theory, viewing it as analytically constrictive to how power should be conceived in the 
colonial complex. For one, the universalising nature and utopianism of Marxian-derived theory renders it largely ineffectual to the diversity of Indigenous studies. Michel Foucault argues, 'if power was never anything but repressive, if it never did anything but say no, do you really believe that we should manage to obey it'. ${ }^{5}$ Although this may seem crude, especially given that I know plenty of Indigenous people who manage to obey repressive forms of power, it points to the premise that hegemonic power is no longer sophisticated enough to explain, for instance, the bodily practices of Indigenous peoples. Thus, I suggest that Indigenous studies conceive of power as 'post-hegemonic'. ${ }^{6}$ Scott Lash writes that there has been 'a shift in power from the hegemonic mode of "power over" to an intensive notion of power from within (including domination from within) and power as a generative force'. ${ }^{7}$ Here, power is not conceived of as hierarchical but rather as internalised with the subject and, consequently, it is the everyday living of the Indigenous subject, the immediacy of Indigenous practices, that becomes fundamentally important.

Hegemony theory served a purpose in providing an intellectual space where Indigenous scholars could meet to discuss the inflection of power within their various contexts. The importance of theory in this regard has not changed, yet as Indigenous scholars we must continue analysing and theorising power in different and creative ways. Led by only a handful of Indigenous scholars (many of whom appear in this special issue of Cultural Studies Review), such as Aileen Moreton-Robinson, the analyses of power and indigeneity through more sophisticated modes of thought is only now beginning to gain any impetus.

It is also commonly recognised within Indigenous studies that colonised societies remain divided along coloniser and colonised lines, and that the historical and contemporary subjugation of Indigenous cultures is where such a division gains its currency. Hence, the strategic attention to 'preservation' among Indigenous studies departments. Such an epistemology, however, carries the ontological blunder of divorcing what it means to be Indigenous from the present. In terms of Indigenous resistance to colonial power, Hegel's 'power of negation' explains the omnipresent duality of consciousness, where colonised Indigenous populations come to define themselves through resistance to the coloniser. Where the colonised and the coloniser, as Hegel puts it, 'prove themselves and each other through a life-and-death struggle'. ${ }^{8}$ According to Albert Memmi, 'the bond between colonizer and colonized is thus destructive and creative. It destroys and re-creates the two partners of colonization into colonizer and colonized. One is disfigured into an oppressor ... the other into an oppressed creature. ${ }^{9}$

Perhaps, then, 'decolonisation' should focus on the continued inhabitance of Indigenous consciousness by a will to resist the coloniser, whether s/he be imaginary or not. For such a dialectic is not a healthy state of mind; constant referral to the power another holds over oneself can only lead to the state where Indigenous people romanticise a pure-precolonial past, are anxiety ridden in the present dialectic, and resigned to a future where our 
identities will be tied to an eternal colonial struggle. As witness to the current academic discourses surrounding Indigenous resistance (underpinned by the notion of 'decolonisation'), it seems to me that the oppressed creature, in its evolution, has developed a 'holier-thanthou' self-righteousness, personified by 'the 70s Indian' who, instead of theorising and articulating their subjectivity, reverts to tears and self-pity. As articulated by Audra Simpson:

Here we have mental distress as an etiology of colonialism itself, whereby the category of Indian, already established as one ... of being a problem, but then in these analyses being a problem that 'has problems' that now have to be dealt with ... [that is, to] fetishize and pathologize this categorical construction as some scholars of "urban native communities" were want to do in the 1970 s... ${ }^{10}$

Here, in briefly turning to Nietzsche, it is possible that the notion of 'ressentiment' can inform the condition of the colonised Indigenous academic.

In relation to the offensive self-righteousness of some Indigenous academics, the comparison between the Christian slave/Roman master dialectic and the colonised/coloniser dialectic cannot be entirely made, because of the obvious ideological importation of Christianity throughout colonisation. Yet, the secularisation of modern colonial settler cultures, and the imbrication of Christianity with what has come to be thought of as 'traditional' Indigenous cultures, allows for some comparison. Thus, motivated by ressentiment against the power of the coloniser, has the ignobility of the secular coloniser become the colonised virtues of Indigenous peoples, such as selflessness, humility and pity? Have the actions of the coloniser been categorised as 'evil' in relation to the 'good', the purity of the virtues of the pre-colonial indigene? Like the Christian slave, has the colonised indigene repositioned a morality in hope the coloniser acquiesces to the moral conduct of the colonised? Nietzsche points out that the Christian slave via moral inversion was tactically successful and, thus, teleologically prudent. Yet, by the nineteenth century, Christianity had exceeded its teleological function and, hence, the 'Death of God' was foretold.

It is possible that the inversion of colonised morality has underpinned the decolonial movement since the late-1960s and that, similarly, its teleological capacity is now foundering. The pity sought by common Indigenous academic discourses not only falls on deaf ears, it limits Indigenous people to a colonised/coloniser mentality, while ignoring Indigenous responsibility in the immediate context. While, in the parlance of our times, 'crying is healthy', nevertheless the amount of tears that flow at Indigenous academic conferences never ceases to amaze. The physiological reaction of tears to colonial occupation is not surprising if our past, present and future appears limited to an eternal struggle with the coloniser. A state of mind critiqued by Sartre's body-notion of 'jumping-for-joy'. Colonised Indigenous ressentiment 
must be replaced by an Indigenous mindset that takes 'responsibility' for colonisation, not to release the coloniser from responsibility, rather to reclaim freedom to choose beyond a colonised/coloniser mentality. Self-determination is key, not based on guilt and pity, rather based on an existentialism underpinned by freedom and choice.

- II

\section{THE BODY AND INDIGENOUS EXISTENTIALISM}

\section{Indigenous studies, cultural studies and the immediacy of Indigenous culture}

The central point to be carried through from the previous discussion is that the typical foci of 'tradition', 'decolonisation' and 'ressentiment' within Indigenous studies combined with colonial representations of Indigenous peoples as 'primitive' and 'pre-modern' has encouraged Indigenous people to locate cultural knowledge beyond their lived experiences and choice. Indigenous existentialism underscores the importance of the lived experience of Indigenous peoples. Indigenous existentialism moves beyond ressentiment and the focus on 'decolonising the mind' to one of choice and responsibility lost at the juncture of the primitive indigene/ civilised European binary; lost when Indigenous peoples became 'victims' of colonisation. Indigenous existentialism implores Indigenous peoples to move beyond victimhood to reclaim choice and responsibility within their lived experiences.

It is at this point, in recognising the importance of Indigenous existentialism and its location in the 'everyday', as opposed to the pure-precolonial past, that the dialogue between Indigenous studies and cultural studies begins. The canonical focus on culture as tradition by Indigenous studies departments around the world is not only a symptom of the internalisation of indigeneity as pre-modern, it also mimics the narrow definition of 'culture' as a derivative of modernity, that is, 'as the objects of aesthetic excellence ("high art")'. ${ }^{11}$ To use Mäori as an example, when 'culture' is employed in Mäori studies it typically refers to either customary concepts or practices. Seldom does 'Mäori culture' refer to everyday practices, and never does it coincide with those colonial cultural practices welcomed by Mäori, which now hold a great degree of meaning within everyday Mäori culture, such as rugby to Mäori masculinity. Popular culture, such as music, film, television and sport have been consumed, deliberated upon and produced as Mäori culture but are never conceived of as 'Mäori culture'.

The relationship between cultural studies and Indigenous studies becomes apparent when culture is understood as 'texts and practices of everyday life', which can include the narrow definition above, but more importantly 'can range beyond its social exclusivity, to include the study of popular culture'. ${ }^{12}$ Given the typical canonistic focus on cultural tradition, the challenge for Indigenous studies is to recognise the existential importance of 'the everyday' in its definition of 'culture'. Everyday culture and traditional culture must form a 
composite of an Indigenous sense of self if a healthy Indigenous epistemology is to take hold. For Indigenous people (as with all people) there is nothing more immediate and everyday than the body.

\section{Exhuming ghosts: A genealogy of the Indigenous body}

Indigenous studies, as with feminist cultural studies, is best to position itself outside the Western, white masculine intellectual tradition of mind/body dualism: 'an approach which refuses to privilege mind over body ... and which assumes that the body cannot be transcended, is one which ... emphasises contingency, locatedness, the irreducibility of difference, the passage of emotions and desire, and the worldliness of being. ${ }^{13}$ Such a positioning is double-edged, however, as the colonial project 'limited the identity of the colonised to the materiality of their bodies ${ }^{14}$ and thus the analysis must be at once deconstructory and existential. Meaning, it is dangerous ground not to firstly problematise Indigenous theorisation stemming from the body, prior to foregrounding the body as a realm of study from where Indigenous existentialism can develop. Hence, this sub-section entitled 'exhuming ghosts'.

In part, white colonial patriarchy effected colonisation because it claimed to embody the power of reason and, consequently, universal interests. Key to enlightenment rationalism and its reliance on reason to know and to authenticate the objective world was its faith in the mind/body dichotomy orated by Plato and canonised by Descartes. In his 1871 book, The Descent of Man, ${ }^{15}$ Charles Darwin emphasises the key differences in intellectual development (that is to say language, observation, curiosity, memory, imagination and reason) between primitive and civilised peoples. ${ }^{16}$ Darwin and other evolution theorists played an indirect but nonetheless highly significant role in the tainting of European accounts of Indigenous peoples. Indigenous cultures as unenlightened were, from an occipital logic, inherently more 'physical', ruled by their passions, and less intelligent than their civilised brethren. The apparent lack of division between the indigene's mind, body, spirit and the external world only served to augment the belief of European colonisers that they were indeed encountering savage races. Moreover, Enlightenment philosophers avoided questions of inconsistency in equality and autonomy arising from colonial subjugation by locating the Indigenous being in the realm of the physical and irrational, a site that denied full humanity itself. ${ }^{17}$

If savagery is understood from the perspective of Enlightenment rationalism, then it is apparent that it portends a state of unenlightenment, where reason is ruled by physical impulses and/or superstition. What Foucault refers to as the invisible 'breath' that inhabits discontinuous discourses, even as they mutate, ${ }^{18}$ I conceive of as 'physicality' with reference to the colonised Indigenous savage. As a sub-theme of the primitive/modern dialectic, physicality describes a complex of interconnecting discourses that enables unitary discursive knowledge to develop around the colonised Indigenous subject. The thematic of Indigenous 
physicality in the colonial state was 'capable of linking, and animating a group of discourses, like an organism with its own needs, its own internal force and its own capacity for survival'. ${ }^{19}$ Darwin's evolutionary theory, for instance, 'directed research from afar' acting as 'a preposition rather than named, regrouped, and explained ... a theme that always presupposed more than one was aware of ... forcibly transformed into discursive knowledge' ${ }^{20}$ Such discursive knowledge underpinned Indigenous 'savagery' and was transcribed into physical terms, onto the Indigenous body and about Indigenous bodily practices.

For this essay, it is important to establish that the collision of supposedly embodied Indigenous epistemologies with disembodied Enlightenment rationalism left an inauthentic void that the Europeans, at least, desired to chart through authenticating disciplines such as anthropology and archaeology. Enlightenment reason, as the determinant of truth and falsehood, was applied to the untranslatable-the epistemologies of other cultures. The process involved, firstly, authenticating Indigenous knowledge by translating the untranslatable. That is, by encompassing and reconfiguring the incomprehensible into comprehensible forms. The authentication element in this equation is crucial because from the premise of the Enlightenment reason, knowledge was only authentic if it was known to the mind. That is, the embodied cultural concepts from 'other' epistemologies were only authentic if they were comprehensible to Western cognition. The first principle of colonising the Indigenous body, then, was to bring the philosophical underpinnings of the savage under the logic of the coloniser, to authenticate the inauthentic. ${ }^{21}$

In the universe of disembodied Enlightenment rationalism, it was assumed that reason (that is, European reason) could differentiate between truth and falsehood and, thus, the physical world was inherently translatable. The embodied practices of Indigenous epistemologies challenged that knowable world and, as a result, the reason of Enlightenment rationalism. The embodied holistic epistemologies of Indigenous societies determined the non-compartmentalisation of the 'physical'. As opposed to the rational European subject, Indigenous subjectivity was not divorced from the body, nor the rationale from the passions, and so forth. ${ }^{22}$ It is also important to recognise Indigenous subjectivities and their consequent bodily practices were often communally defined. Here the distinction can be made with the Western individual subject (who has prevailed in Western thought since the Enlightenment), whose person is comprised of a central and unique core, which determines their distinct identity. The dissimilarity is important because, as opposed to a singular self, it indicates an Indigenous existentialism that incorporates multiple identities across time, including genealogical and spiritual associations, and communally defined bodily practices.

The importance of the visible appearance of indigeneity and its genealogical tithing to moral deficiencies cannot be underestimated to the conception of the Indigenous body today. The Western conception of what it means to be Indigenous is in great part a visual 
phenomenon, 'with all the political and ideological force that the seemingly naturalness of the body as the locus of difference can claim ... [a] cultural training that quite literally teaches the eye not only how but what to see'. ${ }^{23}$ Allegorically, it is crucial to make the connection of the rationality of the European with the body of the colonised Other, underscored by:

the eighteenth century resurrection of classical values of beauty and their similitude with the criteria of value in the classical economic tradition. Equilibrium and utility functioned in classical economic theory in ways analogous to proportion, symmetry, and refinement for classical aesthetics. Both sets of criteria determined an order of balance and harmony established on the basis of the geometric model ... By the late eighteenth century, beauty was established in terms of racial properties: fair skin, straight hair, organthous jaw, skull shape and size, well composed bodily proportions, and so on. To fail to possess these traits was considered a fault inheritance ... Aesthetic value solidified into natural law, which in the eighteenth century was considered as compelling as the laws of nature, economics and morality precisely because they were all deemed to derive from the same rational basis. ${ }^{24}$

The corporeal 'reality' of the asymmetrical Indigenous body undoubtedly naturalised colonial endeavour and Indigenous subjugation, allowing colonialist claims to moral superiority dependent upon what Robyn Wiegman refers to as 'bodily fictions' that 'unproblematically reflect the natural meaning of flesh'. ${ }^{25}$ Here, Bourdieu is useful as he conceives of the body metaphorically: 'the bearer of symbolic meaning and values and a key site through which social differences are created, perpetuated and reinforced'. ${ }^{26}$

Bourdieu is also useful in thinking of the Indigenous body in terms of 'physical capital', 27 especially in relation to mind/body duality in that symbolic meaning inscribed onto the Indigenous body determined inferior mental capacity and thus only contained capital in the inverse sense. The Indigenous body symbolised the physical realm and, thus, was employed for its physical labour, observed for its performativity, and humanised through the physical pursuits of sport. ${ }^{28}$ For many of the Indigenous parents of my generation, Bourdieu's analysis becomes important because of its concern with the body in relation to the working class who, through bodily cognition as a necessary effect of a physically intensive life, developed different relations to their bodies than the white middle or dominant classes. ${ }^{29}$ Moreover, for Indigenous communities, sub-cultures developed throughout much of the twentieth century based on a relationship with a physically labouring body that, in turn, has come to symbolise traditional Indigenous cultures. For instance, the relationship between physical labour and sport with the Mäori male body has determined a traditional Mäori masculinity symbolically reified within the physical realm. ${ }^{30}$ As a consequence, many Indigenous communities remain predominantly working class. However, if we are to perceive of present day culture 
as 'postmodern' then the relationship to the body with work and production becomes less important than an analysis of the fragmentation of the Indigenous body within late-capitalism.

\section{Theorising the immediacy of the Indigenous body}

As has been the case in cultural studies, it is crucial to the health of Indigenous studies that the immediacy of the body become an important site of debate. The previous sub-section stressed that the epistemological mind/body dualism of the Enlightenment and, thus, colonisation, must be exhumed prior to conceptualising the body as a site of research where Indigenous existentialism can be developed and probed. While many Indigenous scholars have challenged the mind/body dichotomy by describing holistic Indigenous epistemologies that typically include the physical, spiritual, mental and material reality of place, almost without fail such holistic theorising seeks to authenticate an Indigenous tradition in opposition to the imposition of mind/body dualism. Thus, the Indigenous body has remained a traditional spectre in Indigenous scholarship while lacking any material presence. Ironically then, part of the proposed study of the Indigenous body should be an analysis of how the spectre of tradition remains written upon the Indigenous body. How, for instance, the location of indigeneity in the primitive past marks the Indigenous body in tourist sites and cultural performances or performances of culture. As this sub-section will highlight, it is the genealogical inscription upon the everyday material reality of the Indigenous body where the complexity of the historical and contemporary Indigenous condition must be analysed. Predominantly, such an analysis should be driven towards an Indigenous existentialism that confronts and theorises the everyday materialism of the Indigenous body.

The first step to analysing the body and Indigenous existentialism is to activate (de-pacify) its materiality beyond binary oppositions such as traditional/non-traditional, authentic/ inauthentic, civilised/non-civilised and Self/Other. This transference is an opportunity to move beyond Hegel's dialectic of self and other that has informed and underpins so much of the analyses of colonisation (for example, Frantz Fanon's coloniser/colonised, ${ }^{31}$ Paulo Freire's oppressed/oppressor ${ }^{32}$ ). It is 'logical' that through colonisation itself and recourses to a victim mentality that the dialectic of self and other has consecrated Indigenous studies and that the analyses of the Indigenous condition constantly reverts back to this dialectic to gain the moral high-ground, but such a position constrains Indigenous existentialism and how we reside within the locatedness of our own bodies and historical moments.

Here Foucault's analyses of how such boundaries or grids are constructed and disciplined is important as a starting-point (only) in this endeavour, especially given Hegel's modernity aided Foucault's conceptualisations of an Archaeology of Knowledge. ${ }^{33}$ Regardless, Foucault is important to the present analyses because of how he conceives of power: 'Power is everywhere; not because it embraces everything, but because it comes from everywhere ... Power 
is not an institution, nor a structure, not a possession. It is the name we give to a complex strategic situation'. ${ }^{34}$ Having said this, the full implications of such a conception of power must be at once acknowledged and dismissed if, for instance, we are to conceive of the Indigenous body living and being recognisable beyond the invisibility of such a power complex.

In acknowledgement, then, the profound weave of mind/body duality into the fabric of colonialism has in part enabled the 'biopolitical management of life' within the normalising neo-colonial state. The production of the coloniser/Indigenous Self/Other dialectic has, in part, since colonisation functioned through the bodily enactment of that dialectic. What it means/meant to be an authentic and tradition abiding Indigenous subject was materialised and reified by the bodily enactments of authentically Indigenous bodily practices. What it meant to be a bone fide Mäori man, for example, became intertwined with institutional discourses that located Mäori masculinity within the physical realm, which in turn disciplined through limiting and employing the Mäori male body in physical labour. The testaments of physical labour, such as musculature, callused hands and strength at once signified Mäori masculinity while enacting it. ${ }^{35}$ Sites of work, leisure, home-life, schools and practices such as eating, cleaning and exercising disciplined the Indigenous body throughout colonisation. The formation of colonial states as local offices of the modern state became 'the primary mechanism through which the body and its meanings [we] re regulated'. ${ }^{36}$ Importantly, this construction of colonial power accounts for Hegel's modernity in that it speaks to how the Indigenous subject becomes self-conscious and constituted themselves as social subjects within the colonised Self/Other dialectic, through and because of their body.

Foucault's conception of biopower, ${ }^{37}$ where individuals become aware of themselves and their place in the world through the disciplined nature of their own body, speaks to the material depth of colonisation and, as referred to above, the forlorn nature of a decolonial project. That is, to a large degree Indigenous people cannot deny the embodiment of colonisation. Many try, many delude themselves into thinking this is possible, many develop a schizophrenic envisioning of an authentic Indigenous self, divorced from a self located in the here and now and even their material genealogical reality. Inevitably, such schizophrenia detracts from an Indigenous existentialism that embraces the here and now.

As inferred above, Foucault's concept of power is radical and necessary to help explicate the colonial condition. Foucault's determination of the body's passivity as a symbol of the contested terrain can be, for instance, translated to describe the colonised Indigenous body, where 'they incest it, mark it, train it, torture it, force it to carry out tasks, to perform ceremonies, to emit signs'. ${ }^{38}$ Thus, as Tim Edwards argues, Foucault's theorisation suggests 'the body is not only caught up within this set of relations, but its meaning becomes entirely constituted by them'. ${ }^{39}$ 
However, the unrealisability of the power complex itself demands that an Indigenous existentialism move beyond such a construction to one where freedom, choice and responsibility are recognisable. As with the plea made previously to move beyond the eternal colonised/coloniser mentality, while realising the import of Foucault's theorisation of power, Indigenous peoples must resolve to take responsibility, including responsibility for the disciplining of their bodies via colonisation. Thus, rejecting the idea of the Indigenous body as being merely passively inscripted upon in favour of also conceptualising it as a selfdetermining or 'active biological entity'. ${ }^{40}$

As Indigenous scholars, we cannot ignore the historical inscription upon the Indigenous body, especially as a material occupier of colonised space. Moreover, we should never disavow the embodied pain of our ancestors. Yet, nor can we romanticise the Indigenous body in the search for a pure-pre-colonial past. That is, the importance of strenuous analyses into the immediacy of the Indigenous body as an existing, living, breathing, playing, thinking, working, aging and dying physical agent. Indigenous theorising cannot fully develop without the possibility for existential agency, for it cannot be that the atrocities of colonisation can be the defining point, the point Indigenous existentialism remains scarred indeterminately. Indigenous existentialism must materialise beyond such embodied and genealogical pain. The physical endurance of pain may not be a choice, but Indigenous people can choose to live beyond the genealogical scarring inflicted by colonisation. However, Bourdieu argues that 'It is quite illusory to believe that symbolic violence can be overcome with the weapons of consciousness and will alone, this is because the effect and conditions of its efficacy are durably and deeply embedded in the body in the form of dispositions', ${ }^{41}$ a similar conceptualisation to Fanon's decolonial recourse to violence. Likewise, the material presence of indigenous bodies in sites that disrupt colonial narratives by being situated beyond the disciplinary complex, can subvert. The materiality of an Indigenous body can be drawn into the symbolic realm without ceasing to be a body.

\section{Constructionism and essentialism}

The immediate materiality of the Indigenous body is inescapable. Yet, we need tread carefully, for no better reason than it was the naturalisation of biological racism through the scientific age, which gave credence to the atrocities of colonisation and imperialism. That is, we must strategically recognise the importance of the Indigenous body to the possibilities of Indigenous existentialism without 'collapsing into a form of biological or fatalistic essentialism'. ${ }^{42}$ To date, there is an unresolved dualism with regard to the theorisation of the body hinging upon constructionism and essentialism. Neither position for me is tenable in relation to the Indigenous body nor for a project of Indigenous existentialism for the reasons outlined above. 
Here some intermediary is needed that does not deny the disciplinary nature of power, nor the body's agency. Norbert Elias's theorisation of the body provides some middle ground:

the body is an unfinished biological entity that is both shaped by society and an active player in its formation. A key example here is language, as this is both a socially learned and historically dynamic phenomenon yet one that depends on the development of bodily and cognitive functions to use it. Similarly, birth and death are understood socially, yet remain biological events. ${ }^{43}$

In relation to the Indigenous body, such theorisation would suggest an inseparability between the body and culture; its genealogical inscription, its immediacy, and its projected future. The body's past, present and future in a constant interdependent state with its facticity - its situation. The dilemma Elias leaves us with is that the mutual interdependence of the body and social context can be likened to Foucault's biopower in that ultimately the body cannot be separated from the power complex.

In this discursive power complex it is difficult to disengage with a mind/body duality, and it is at this fundamental level where theorising towards epistemological transformation must begin; the thinking body; the conceptualisation of the body as a material producer of thought; the body as a holistic notion where physiology and the interplay between history, present and future interact to produce social meaning, which may be freeing and/or disciplinary. Such conceptualisations enable a move beyond the limits of constructionism (for example, the passivity of the body described by Foucault) and essentialism (for example, biological determinism). For Indigenous people such an approach makes possible Indigenous existentialism because it suggests that the morphing body through time is both changed and can change its facticity, whilst importantly moving beyond the mind/body dualism at the heart of the construction of Indigenous peoples as bound by their physicality and passions and, thus, their unenlightened savagery. The next sub-section will illustrate how the morphing body can both change and be changed by its facticity through the lens of sport and, in particular, Mäori rugby.

\section{Cultural studies: sport and embodied Indigenous resistance}

Thus far, the present essay has argued for an Indigenous existentialism located in the 'everyday' and, hence, the importance of strenuous analyses into the immediacy of the Indigenous body. Again, it is here that the dialogue between Indigenous studies and cultural studies becomes obvious. Sport, for example, becomes an ideal lens to analyse Indigenous bodies as inscripted upon through the genealogical alignment of Indigenous physicality with the "natural athleticism' of Indigenous people, while also recognising sport as a possible site of 
Indigenous existential opportunity. In this brief sub-section, I would like to focus on the latter. Here, the work of C. L. R. James is important as Simon Featherstone explicates:

James's work consistently emphasizes the capacity of popular cultural forms both to achieve and express awareness of the social formations and historical processes that produced them, and through the awareness to participate in challenge and change ... For him, the body in movement was a dynamic sculpture shaped by a dialectical tension individual will and desire, and the forms and constraints of its social environment at a particular historical moment. Whilst the body has always been at the painful centre of colonial and imperial history, it was James who first articulated its capacity for expression and resistance, not through violence necessarily, but through the detailed aesthetics of the body's response to stimuli at a particular moment in history. The political theatre of movement occurs in various and unexpected places by no means limited to traditional definitions of 'art' or rebellion: in a batman's stroke in cricket. ${ }^{44}$

Similarly, for a particular historical moment prior to late-capitalism the body in movement through Mäori rugby demonstrated a capacity for subversion, an unorthodox 'style' that did not adhere to the disciplinary regime in colonial sport. ${ }^{45}$ Where game-plans, for instance, governed by master-plans based on safety and efficiency were replaced with an aesthetics of the body. For example, renowned for his own unorthodox style, ex-Mäori All Black Tutekawa 'Tu' Wylie explicates subversion through play:

Maori play a particular type of rugby. It's spontaneous and exuberant. In rugby we celebrate the joy of living. So we're prepared to take risks and to do things just for the hell of it. In our day it wasn't whether we won or lost but the way we played the game ... I don't know whether that's being coached out of our players. And I don't know whether New Zealand rugby has room now for our philosophy. ${ }^{46}$

Wylie talks of a different approach to rugby, a variant philosophy, which brought an aesthetic of subversion to bodily play, and countered the rational and utilitarian foundations that have pervaded modern sport; where Mäori players 'did things just for the hell of it'. Through bodily expression in Mäori rugby, the Mäori athlete became invested in an economy of loss in opposition to the 'win at all costs' mentality that evolved in New Zealand colonial rugby, and the frontier colony itself. At times, the Mäori body played to play.

The notion of play is important to understanding the immediacy of the Indigenous body because it locates the body outside the disciplinary complex that Foucault describes. It acknowledges at least the existential possibility of freedom beyond disciplinary constraint. It also provides the possibility for providing an existential space beyond Foucault's construction of power where power is everywhere; not to say that power can be possessed, rather 
that Indigenous people, for instance, have the existential wherewithal to be free. Even Foucault himself stated that people 'are much freer than they feel, that people accept as truth, as evidence, some themes which have built up at a certain moment during history, and this so-called evidence can be criticized and destroyed'. ${ }^{47}$ In relation to the body then, style or how Indigenous people self-style material interactions with the historical moment will determine in part how social interactions will proceed.

\section{- Conclusion}

Albert Camus' The Plague metaphorically describes the people of Paris under German occupation as located within a plague ridden, quarantined city. Camus' existential critique points out that, firstly, people's consciousness and beliefs surrounding the situation they find themselves determines how they conceptualise the past, present and future and, secondly, that it is a choice to view one's facticity, one's situation, in such limited terms. Camus refers to occupation in terms of people's perceptions of possibility as opposed to the enforced plague upon the city itself. In the colonial context, Camus' existentialism provides a lens for how Indigenous people conceive of the Indigenous body. Do we romanticise the Indigenous body as part of the pure-pre-colonial past, scarred and traumatised by the rupture of colonial invasion? Are Indigenous bodies anxiety ridden in the present, lost between the pure past and the impure present; racked by tears over the actions of others upon us? Do we feel cheated of the future? Does the birth of our children lack responsibility; that is, will we pass on to them as part of our bodily 'traditions', the tears of self-pity? Conversely, can we 'jump for joy' in the knowledge that regardless of our facticity, we have choice, responsibility and freedom.

Effecting an Indigenous existentialism through the realisation of the material immediacy of the Indigenous body will enable Indigenous people to live beyond the search for a purepre-colonial past and the limits of a mind/body duality. Yet, take stock. If we are able to conceive of our bodies beyond the discursiveness of power, then we will realise that we do not know the potential of our bodies at all. Enlightenment rationalism determined the universe to be knowable and inherently that the bodies were matter and, therefore, understandable. If the European could not know/control their bodies, that is, themselves and the bodies of other humans, then the larger Enlightenment project was hopeless. Thus, part of the Enlightenment project was to civilise bodies, to discipline them within the discourses of the age of reason. Accordingly, if we are able to come to recognise the indistinguishable taxonomies that discipline our bodies, then we realise that we do not know our own bodies at all: their potential; their savagery; their horrors; their power. An Indigenous existentialism will recognise that the power of the body is still unknown and it is our choice to investigate the abyss. 
BRENDAN HOKOWHITU is Ngati Pukenga. He is the program coordinator of the Master of Indigenous Studies in Te Tumu, the School of Maori, Pacific and Indigenous Studies at the University of Otago, New Zealand. His research interests include Indigenous theory and popular culture and, in particular, masculinity and sport.

1. Tejaswini Niranjana, Sitting Translation: History, Post-Structuralism, and the Colonial Context, University of California Press, Berkley, 1992, p. 37.

2. Clea Te Kawehau Hoskins, 'In the Interests of Maori Women? Discourses of Reclamation', Women's Studies Journal, vol. 13, no. 2, 1997 , pp. 25-44.

3. Cited Linda Tuhiwai Smith, Decolonizing Methodologies: Research and Indigenous Peoples, Zed Books, London, 1999, p. 110

4. Smith, p. 34

5. Michel Foucault, Discipline and Punish: The Birth of the Prison, trans. A. M. Sheridan, Vintage/Random, New York, 1979, p. 36

6. Scott Lash, 'Power after Hegemony', Theory, Culture E Society, vol. 24, no. 3, 2007, pp. 55-78

7. Lash, p. 56.

8. Michael Peters, 'Cultural Studies and the Future of "Culture", New Zealand Sociology, vol. 16, no. 2, 2001, p. 34

9. Albert Memmi, The Colonizer and the Colonized, London, Oxford University Press, 1967, p. 89.

10. Audra Simpson, "Commentary: The "Problem" of Mental Health in Native North America: Liberalism, Multiculturalism, and the (Non)Efficacy of Tears', Ethos, vol. 36, no. 3, 2008, p. 376

11. Stuart Sim (ed.), The Routledge Companion to Postmodernism, Routledge, London, 2001, p. 218. 12. Sim, p. 218.

13. Sara Ahmed and Jackie Stacey (eds), Thinking Through Skin: Transformations: Thinking Through Feminism, Routledge, New York, 2001, p. 3.

14. Simon Featherstone, Postcolonial Cultures, University Press of Mississippi, Jackson, 2005, pp. 65-6.

15. Charles Darwin, The Descent of Man and Selection in Relation to Sex, John Murray, London, 1871

16. Adam Kuper, The Invention of Primitive Society: Transformations of an Illusion, Routledge, London, 1988.

17. David Theo Goldberg, 'Modernity, Race, and Morality', in David Theo Goldberg (ed.), Racist Culture: Philosophy and the Politics of Meaning, Blackwell, Oxford, pp. 32-3.
18. Michel Foucault, The Archaeology of Knowledge, trans. A. M. Sheridan Smith, Routledge, London, 2002, pp. 28-9.

19. Foucault, The Archaeology of Knowledge, p. 39

20. Foucault, The Archaeology of Knowledge, p. 39.

21. Brendan Hokowhitu, 'Authenticating Mäori Physicality: Translations of "Games" and

"Pastimes" by Early Travellers and Missionaries to New Zealand', International Journal of the History of Sport, vol. 25, no. 10, 2008, pp. 135-73.

22. Hokowhitu, 'Authenticating Mäori Physicality', pp. 135-73

23. Robyn Wiegman, American Anatomies: Theorizing Race and Gender, Duke University Press, Durham, 1995, p. 22.

24. Theo Goldberg, p. 30

25. Wiegman, p. 21

26. Tim Edwards, Cultures of Masculinity, Routledge, New York, 2006, p. 145.

27. Pierre Bourdieu, Distinction: A Social Critique of the Judgement of Taste, trans. R. Nice, Routledge \& Kegan Paul, London, 1984.

28. Brendan Hokowhitu, 'Race Tactics: The Racialised Athletic Body', Junctures: The Journal for Thematic Dialogue, vol. 1, 2003, pp. 21-34.

29. Bourdieu, Distinction.

30. Brendan Hokowhitu, 'Tackling Mäori Masculinity: A Colonial Genealogy of Savagery and Sport', The Contemporary Pacific, vol. 15, no. 2, 2004, pp. 259-84.

31. Frantz Fanon, The Wretched of the Earth, trans. C. Farrington, Penguin, London, 1967.

32. Paulo Freire, Pedagogy of the Oppressed, trans. M. Bergman Ramos, Seabury Press, New York, 1973.

33. Foucault, The Archaeology of Knowledge.

34. Michel Foucault, The History of Sexuality, trans. R. Hurley, Vantage Books, New York, p. 93.

35. Brendan Hokowhitu, 'Mäori Physicality: Stereotypes, Sport and the "Physical Education" of New Zealand Mäori', Culture, Sport, Society, vol. 6 no. 2, 2003, pp. 192-218.

36. Edwards, p. 141.

37. Foucault, The History of Sexuality.

38. Michel Foucault, 'The Body of the Condemned', trans. A. Sheridan, in Henrietta Moore and Todd 
Sanders (eds), Anthropology in Theory: Issues in Epistemology, Blackwell Publishing, Malden, 2006, pp. 352-56.

39. Edwards, p. 144

40. Edwards, p. 142.

41. Pierre Bourdieu, Masculine Domination, Stanford University Press, Stanford, 2001, p. 39

42. Edwards, p. 151

43. Edwards, p. 149

44. Featherstone, p. 27.

45. Brendan Hokowhitu and Jay Scherer, 'The Mäori All Blacks and the Decentering of the White
Subject: Hyperrace, Sport, and the Cultural Logic of Late Capitalism', Sociology of Sport Journal, vol. 25, 2008,

pp. 243-262.

46. Waihorai Shortland, 'Paradise Lost', Mana, January/February, 1993, p. 47.

47. Michel Foucault, 'Truth, Power, Self: An Interview with Michel Foucault-October 25th, 1982', in

Luther H. Martin, Huck Gutman and Patrick

H. Hutton (eds), Technologies of the Self: A Seminar

with Michel Foucault, Tavistock, London, 1988,

p. 9 